\title{
EFFECT OF PLANTING DATES AND DRIP IRRIGATION RATES ON GROWTH, YIELD AND ITS COMPONENTS OF COWPEA (VIGNA UNGUICULATA L. WALP) PLANTS UNDER SANDY SOIL CONDITIONS
}

\author{
R. H. M. Geeth \\ Self-Pollination Veget. Dept.; Hort. Res. Inst.; Agric., Res. Center, Giza, Egypt. \\ Received: Jan. 22, 2019 \\ Accepted: Feb. 9, 2019
}

\begin{abstract}
Two field experiments were carried out in privet farm at Bani Mazar region, North Al-Minia Governorate, Egypt, during the two fall seasons of 2016 and 2017, respectively under drip irrigation system, in sandy soil conditions. The objectives of this experiment were to study the effect of two factors i.e. determine the proper planting date from three planting dates i.e. at middle of July (as a control), $7^{\text {th }}$ and $28^{\text {th }}$ of August at twenty one days interval as well as two water schedule regimes treatments i.e. 80 and 60 $\%$ from water requirements/ fed. as compared with the control treatment i.e. $100 \%$ from the cowpea (Vigna unguiculata L. Walp) plants irrigation requirements/ fed. and their interactions on growth, yield, its components, water use efficiency as well as some chemical constituents of the leaves and dry seeds under the condition of the newly reclaimed soil on the cowpea Kaha $1 \mathrm{cv}$. The experimental design was split-plot, i.e. the three planting dates devoted in the main plots and the water schedule regimes randomly distributed in the sub plots with three replications per treatment.
\end{abstract}

The results indicated that, the best planting date under this investigation was at middle of July as compared with the two other planting dates i.e. $7^{\text {th }}$ and $28^{\text {th }}$ of August which occurred the highest significantly increased in vegetative growth characters, dry seeds yield (ton/ fed.), its components, water use efficiency, total chlorophyll content in the fresh leaves, proline contents in the dry leaves, protein, nitrogen, phosphorus and potassium (\%) in the cowpea dry seeds.

Concerning to the influence of schedule water regime, it was found that, the cowpea plants received the complete irrigation treatment $(100 \% /$ fed.) as compared with increasing water deficient from $80 \%$ to $60 \%$ from the cowpea plants irrigation requirements/ fed. produced no significant increases in some characters i.e. plant height, dry weight of the foliage/ plant, average weight of dry pods, number of dry seeds/ pod, weight of $\mathbf{1 0 0}$ dry seeds and total chlorophyll content in the fresh leaves.

Whereas, the cowpea plants irrigated with the moderate irrigation treatment $(80 \%$ from the cowpea plants irrigation requirements/ fed.) led to no significant increases in number of branches, dry seeds yield, number and weight of dry pods/ plant, proline contents in the dry leaves, protein, nitrogen and potassium (\%) contents in the dry seeds.

The lowest results of all previous characters were obtained when the plants were irrigated with the lowest water amount i.e. $60 \%$ from the cowpea plants irrigation requirements/ fed. as compared with the two other water schedule regimes. On the other hand, water use efficiency significantly increased with irrigation the cowpea plants with $60 \% /$ fed. followed with irrigation with $80 \%$ and $100 \%$ from water requirements / fed.

Regarding to the results of the interactions between the two studied factors used in this study showed that, the distinguished interactions treatment which led to the highest antecedent means values over all the other interactions was obtained with the interaction 
between the $1^{\text {st }}$ planting date at the middle of July and irrigation the cowpea plants by the moderate irrigation regime ( $80 \%$ from the cowpea plants irrigation requirements/ fed.) specially, its produced significant increases in dry seed yield and its components as well as water use efficiency as compared with the rest of the two interactions, these findings were true in the both fall seasons.

Key words: Cowpea, Planting dates, Irrigation schedule regimes, Water use efficiency and Newly reclaimed soil.

\section{INTRODUCTION}

Cowpea (Vigna unguiculata (L.) Walp) is one of the most important food grain legume crops in Egypt as well as other tropics and sub-tropics countries. The nutritional values of the cowpea grains are important because it is eaten by several millions people who otherwise have diets lacking in protein, minerals and vitamins. The nutritional of the cowpea grain is a relatively low fat content and total protein content but it is contain two to four times greater than cereal and tubers crops from these components. Its dry-seeds have high percentage which consider as a cheap source of protein for the poor protein $(20$ to $30 \%$ ) that characterized as a complete protein compared with those of other vegetables. The protein in cowpea grains are rich in the amino acids such as lysine and tryptophan, compared to the cereal grains. However, it is deficient in methionine and cystine when compare with the cereal crops. The green leaves are prepared as a pot herb, like spinach, in addition its immature green pods is used in the same way as snap beans (Belay et al., 2017).

Planting date and appropriate water regimes are the major factors responsible for successful the cowpea production especially under the newly reclaimed desert areas in Egypt. In this respect, planting date is one of the important cultural practices results in the greatest differences in growth and yield of grain legumes, sowing cowpea seeds at the optimum time enables the crop to best use the available growth factors such as temperature and solar radiation at different stages of growth led to ensure good plants establishment, flowering and pod filling stages for maximum seed yield. Cowpea is consider as an adaptable to harsh environments including extreme temperatures and water limiting conditions as well as other biotic stresses compared with other crops. The optimum soil temperature for rapid germination of the cowpea seed is above $18.3^{\circ} \mathrm{C}$, but the minimum base temperature to initiate germination can be $\left(7-14^{\circ} \mathrm{C}\right)$, chilling damage can cause slow and incomplete emergence. Cowpea is adapted to high temperatures in the range, $20-35{ }^{\circ} \mathrm{C}$, it does not withstand flooded conditions. It grows under a wide extreme of moisture and once established it is fairly tolerant to drought and can give good yields under marginal rainfall but in high rainfall areas (Dugje et al., 2009).

Regarding to, the water regimes, water deficit is one of the main factors limiting crop production. It decreases growth, interrupts water relations and reduces water use efficiency in crops; this may be attributed to the strong sensitivity of cowpea stomata to water stress with reduction in photosynthetic capacity, which this attributed to the effect of drought on water use efficiency to stomatal closure, decreased transpiration and decreased leaf turgidity, which have consequences on photosynthesis (Farooq et al., 2012).

Additionally, one of the most challenges facing the agriculture of Egypt is a serious in shortage of water 
resources, with a continuously increasing population. Irrigation water is one of the most important factors for increasing agricultural production. Water is a very limited resource and most of Egypt's water uses are for the agriculture sector, which consumes about $84 \%$ from water amounts. The increasing gap between the available renewable water resources so it is advised to evaluate new possible approaches to minimize the plant water consumption and hence to rationalize irrigation water use, Egypt, like many other countries which lie in arid and semi-arid region, is subjected to water scarcity (FAO, 2013). Climate change (rising of temperature and lowering of precipitation), misuse of water resources, pollution and inefficient agriculture irrigation techniques besides rapid rising of population are the major factors that aggravate water security problem in the country. Egypt was demanded saving water irrigation by using drip irrigation which it is the best and the most suitable method for the irrigation of the cowpea plants especially in the sand soil compared to surface irrigation for many reasons i.e. drip is the most efficient way to irrigate. It is usually about $90 \%$ efficient compared to about $70 \%$ for sprinkler and often $50 \%$ for surface irrigation which has to be applied in the newly reclaimed desert areas as well as old Delta soils, for saving much irrigation water especially for using its under the old Delta conditions instead the traditional surface irrigation system. A drip irrigation system makes fertigation and chemigation easy and convenient, plant foliage stays dry with drip and therefore there are fewer problems with plant diseases that do better on wet leaves and in humid conditions as well as a large portion of the soil surface always stays dry (Abdel-Raouf, 2015).

The main objectives of this study were to identifying the optimal planting dates, exact irrigation regime and their interactions to enhance growth, dry pod characters, dry seed yield productivity, water use efficiency and some chemical properties, in order to be saving $20 \%$ from the cowpea plants irrigation requirements/ fed. grown under the newly reclaimed of sandy soil conditions without any reduction on dry seed yield and its quality.

\section{MATERIALS AND METHODS}

Two field experiments were carried out during the two fall seasons of 2016 and 2017 in sandy soil of private farm at Bani Mazar region, North Al-Minia Governorate, Egypt. Coordinates: its located $28.50^{\circ}$ North latitude and $30.80^{\circ}$ East longitude and it is situated at elevation 43 meters above sea level. The objectives of this study were to determine the exact of the date planting, water schedule regimes and their interactions under the condition of the newly reclaimed soil on growth, yield, its components, water use efficiency as well as some chemical constituents of leaves and cowpea dry seeds Kaha 1 cv.

The experimental design was splitplot; the treatments were arranged in a complete randomized block design with three replicates. The main plots were devoted for three planting dates (factor A) i.e. $1^{\text {st }}$ (planting date at the middle of July), $2^{\text {nd }}$ (planting date at the seventh of August) and the $3^{\text {rd }}$ (planting date at $28^{\text {th }}$ of August) at twenty one days interval, of 2016 and 2017 seasons, respectively. The drip irrigation system was used (including GR dipper, with discharge rate of $4 \mathrm{LI} \mathrm{h}$ was spaced at $25 \mathrm{~cm}$ intervals) to apply the three levels of water schedule regimes (factor $B$ ) as sub plots, i.e. $100 \%$ (full irrigation) with $1500 \mathrm{~m}^{3}$, $80 \%$ (moderate stress) with $1200 \mathrm{~m}^{3}$ and $60 \%$ (severe stress) with $900 \mathrm{~m}^{3}$ waterl fed., respectively from the cowpea plants irrigation requirements/ fed. through the season. Total water irrigation ( $\mathrm{m}^{3} /$ fed.) was estimated according to the meteorological data of the Central Laboratory for Agricultural Climate, 
Agricultural Research Center, Ministry of Agriculture, Giza, Egypt under the condition at Bani Mazar region. All experimental units were received equal amounts of water until the complete germination (15 days from each seed sowing date) then irrigation treatments were started in the both fall seasons.

Seeds of the cowpea Kaha $1 \mathrm{cv}$. were purchased from Horticulture Research Institute, Agricultural Research Center; the area of the experimental plot for every treatment was $11.2 \mathrm{~m}^{2}$. Each plot consisted of 4 dripper lines at $4 \mathrm{~m}$ in length and $0.7 \mathrm{~m}$ in width, seeds were sown with three seeds/ hill at 7-10 cm apart on one side of dripper lines. After complete emergence, plants were thinned to one plant for hill.

The recommended agricultural practices of the cowpea plants in this area such as fertigation method, weed control and pest management were applied during the two fall growing seasons according to the recommendations of Egyptian Ministry of Agriculture.

The meteorological data for the experimental area obtained from Central Laboratory for Agricultural Climate (CLAC), Agricultural Research Center (ARC), Ministry of Agricultural and Land Reclamation, values were recorded during the two fall growing seasons as shown in Table 1.

Soil samples were randomly collected each year before cultivation at a depth of 0-30 cm in order to measure the important of the physical and chemical properties which determined according to (Jackson, 1973) were shown in Table 2.

Table 1: Meteorological data at Bani Mazar region, Al-Minia Governorate during the two fall seasons of 2016 and 2017

\begin{tabular}{|c|c|c|c|c|}
\hline \multirow{2}{*}{ Months } & \multicolumn{4}{|c|}{ Air temperature ${ }^{\circ} \mathrm{C}$} \\
\cline { 2 - 5 } & \multicolumn{3}{|c|}{2016} & \multicolumn{2}{c|}{2017} \\
\cline { 2 - 5 } & Maximum & Minimum & Maximum & Minimum \\
\hline July & 40.0 & 20.5 & 39.5 & 20.6 \\
\hline August & 40.0 & 19.3 & 39.0 & 19.4 \\
\hline September & 38.0 & 17.1 & 37.0 & 15.6 \\
\hline October & 38.5 & 38.5 & 37.0 & 13.0 \\
\hline November & 33.0 & 11 & 30.3 & 13.2 \\
\hline
\end{tabular}

Table 2: Physical and chemical analysis properties of the experiment soil.

\begin{tabular}{|c|c|c|}
\hline Components & $1^{\text {st }}$ season & $2^{\text {nd }}$ season \\
\hline Soil Type & sand loam & sand loam \\
\hline Organic Matter \% & 0.35 & 0.42 \\
\hline Clay \% & 51.4 & 3.93 \\
\hline Silt \% & 24.66 & .2601 \\
\hline Fine Sand \% & 41.93 & 38.65 \\
\hline Coarse Sand \% & 28.90 & 31.41 \\
\hline pH & 7.79 & 7.96 \\
\hline E.C. (mmhos /cm ) & 0.70 & 0.78 \\
\hline CaCO3 \% & 8.31 & 8.18 \\
\hline Total N (\%) & 0.032 & 0.028 \\
\hline Available P mg/100 g & 37.62 & 38.80 \\
\hline Available K $\mathbf{~ m g / 1 0 0 ~ g ~}$ & 362.6 & 375.9 \\
\hline
\end{tabular}


The following parameters were recorded:

1- Growth parameters: Five cowpea plants from each treatment were randomly chosen at 60 days from each sowing date to measure plant height, number of branches and dry weight of the foliagel plant (leaves and stems).

2-1- Yield and its components: At harvest time i.e. dry pods stages, a random samples of 20 dry pods of cowpea which, were taken from each treatment to determine each of pod length $(\mathrm{cm})$, pod diameter $(\mathrm{cm})$, weight of dry pod (g), number of dry seeds/ pod and weight of 100 dry seeds (g). Number of dry pods/ plant and weight of dry pods/ plant (g) were determined by chosen a random sample of five plants. At suitable maturity dry stage, cowpea dry pods were threshed and calculated as total dry seeds yield as (ton/ fed.).

2-2-Water Use Efficiency: Water use efficiency (WUE) is an indicator of the efficiency of irrigation in increasing cowpea crop yield. Water use efficiency $\left(\mathrm{Kg}\right.$ yield $l \mathrm{~m}^{3}$ water) was calculated from the following equation of Rahil and Qanadillo, 2015:-

WUE $=$

Dry seed yield (Kg/ fed.)

Total applied of irrigation water $\left(\mathrm{m}^{3} / \mathrm{fed}\right.$.)

3-Chemical composition in the leaves and dry seeds:

3-1- Minerals contents: Fresh samples of the cowpea leaves and dry seeds were dried in an electric forced-air oven at $70^{\circ} \mathrm{C}$ to constant weight then fractionated and sifting. The fine powder (at $0.2 \mathrm{~g}$ ) of each dry sample was digested in a mixture of sulphuric and perchloric acids, as wet digestion according to Piper (1947). Total nitrogen, phosphorus and potassium contents (\%) in dry seeds were determined according to Bremner and Mulvaney (1982), Olsen and Sommers (1982) and Horneck and Hanson (1998), respectively.

3-2-Total chlorophyll content (mg/ $100 \mathrm{~g}$ of fresh weight): Was determined at 60 days from each sowing date in the fresh leaves (random sample of five fresh leaves from the plants topl plot), according to Nagata and Yamashita (1992).

3-3-The free proline content ( $\mathrm{mg} / \mathrm{g})$ : In dry leaves was determined according to the method described by Troll and Lindsley (1955).

3-4-Protein (\%): Were determined in dry seeds through the determination of total nitrogen and a factor of 6.25 was used for conversion of total nitrogen to protein percentage according to Kelly and Bliss (1975).

4- Statistical analysis: All obtained data of the present study was subjected to the analysis of variance techniques according to the design used by the MSTATC computer software program variance and mean of treatments were compared according to the Least Significant Differences (L. S. D.) test at the 0.05 probability level, method described by (Bricker, 1991).

\section{RESULTS AND DISCUSSION}

I- Vegetative growth parameters:-

1-1-Effect of planting dates:

Data pertaining in Table, 3 on plant height, number of branches/ plant and dry weight of the foliagel plant of the cowpea plants indicate clearly that the $1^{\text {st }}$ planting date seemed to be the best planting time for vegetative growth of the cowpea plants which it is produced the superior significant increases between the rest of the other two planting dates 
which gave the tallest plant height, the highest number of branches and the heaviest dry weight of the foliage (g)I plant, while the lowest previous traits were recorded at the $3^{\text {rd }}$ planting date (late season). There was no significant difference in number of branches between the $2^{\text {nd }}$ and the $3^{\text {rd }}$ planting dates on the two fall seasons, respectively. Meteorological data of temperature means at the first month from the early sowing date (middle of July) showed that prevalent temperature during germination of the cowpea seeds, were (40:39.5 ${ }^{\circ} \mathrm{C}$ and $20.5: 20.6{ }^{\circ} \mathrm{C}$ ) as the maximum and the minimum temperature in the first and the second seasons, respectively and in this warm condition prevailing may be furnished to better germination which produce healthy plants which lead to causing higher photosynthates having greater fresh and dry weight of the foliage values than the $2^{\text {nd }}$ and the $3^{\text {rd }}$ planting dates. On the other hand, the abundance of growth characters of the cowpea plants. which planted in the $1^{\text {st }}$ sowing date under this investigation may be attributed to the long time of the plants which was took it during the growth stage, higher solar radiation led to the increase potential photosynthesis production as well as the longer duration of the growth period, consequently produce the better growth characters as compared with the rest of the two other planting dates. Additionally, the cowpea is a heat-loving and drought-tolerant crop, the optimum temperature for growth and development is around $35^{\circ} \mathrm{C}$ as mentioned before by (Dugje et al., 2009). Similar trends were reported by Ezeaku et al. (2015) they reported that the $1^{\text {st }}$ planting date at $24^{\text {th }}$ of July gave significantly higher on dry weight, number of internodes, leaves and vine length as compared with the $2^{\text {nd }}$ planting one at the $12^{\text {th }}$ of September which gave the lowest vegetative growth traits of the cowpea plants.

\section{1-2-Effect of water schedule regimes:}

Data presented in the same Table, 3 show that the irrigation schedule regimes (\%) had a significant effect on plant height, number of branches and dry weight of the foliagel plant in both fall seasons. Irrigation at $\mathbf{1 0 0} \%$ from the cowpea plants irrigation requirements/ fed. produced the highest mean values of plant height and dry weight of the foliagel plant, this is explained the increase in dry matter of plants grown in the high levels of soil moisture could be attributed mainly to the effect of water on some quantitative, qualitative changes in certain metabolic processes, enhancing cell division and enlargement which need more water supplies during the vegetative stage. While, the highest values in number of branches/ plant obtained from the cowpea plants received the moderate irrigation stress regime i.e. $80 \%$ from the cowpea plants irrigation requirementsl fed. No significant differences were detected in the $1^{\text {st }}$ and the $2^{\text {nd }}$ irrigation schedule regime (\%) under the condition of this investigation in the first and the second seasons, respectively.

The decrement in all studied growth aspects significantly gained with increasing water stress levels from $80 \%$ to $60 \%$ from water requirements/ fed. The largest reduction in growth characters of the cowpea plants were observed under a severe water stress (60\%/ fed.) during the two fall seasons of this study, this may be duo to the shortage of irrigation water caused a reduction in nutrients uptake, metabolism translocation as well as cell division and elongation which decreased plant height, number of branches and dry weight of the foliagel plant. The enhanced production of reactive oxygen species during water stress lead to the progressive oxidative damage and 
ultimately cell death and growth suppression in plant (Ruiz-Lozano et al., 2012). Similar results were also reported by Dalia et al. (2017) who suggested that irrigation the cowpea plants at $70 \%$ of available water of the available soil moisture produced the highest mean values of branches per plant while, the lowest one were obtained when irrigation was applied at $30 \%$.

\section{1-3-Effect of the interactions:}

Significant interactions effects were found between of the two studied factors on vegetative growth of the cowpea plants, data in the same Table, 3 indicate that the tallest plants and the heaviest dry weight of the cowpea foliage were obtained with the surpassing the interactions treatments i.e. sowing at the middle of July with the full irrigation regime i.e. $100 \%$ from the cowpea plants irrigation requirements/ fed. While, the most number of branches occurred with the interactions between sowing at the middle of July and the moderate irrigation regime i.e. $80 \%$ from the cowpea plants irrigation requirements/ fed. The lowest records data on vegetative growth of the previous characters cowpea plants were obtained with the interactions treatment between the $3^{\text {rd }}$ planting date at $28^{\text {th }}$ of August (late season) and irrigation the cowpea plants with severe stress irrigation regime i.e. $60 \%$ from the cowpea plants irrigation requirements/ fed. in the $1^{\text {st }}$ and the $2^{\text {nd }}$ seasons, respectively .

Table 3: Effect of planting dates, irrigation schedule regimes and their interactions on plant height, number of branches and dry weight of the foliagel plant of the cowpea plants during the two fall seasons of 2016 and 2017

\begin{tabular}{|c|c|c|c|c|c|c|c|}
\hline \multirow{2}{*}{$\begin{array}{l}\text { Effect of } \\
\text { planting } \\
\text { dates }\end{array}$} & \multirow[b]{2}{*}{$\begin{array}{l}\text { Irrigation } \\
\text { schedule } \\
\text { regimes (\%) }\end{array}$} & \multicolumn{3}{|c|}{2016} & \multicolumn{3}{|c|}{2017} \\
\hline & & $\begin{array}{l}\text { Plant } \\
\text { height } \\
\text { (cm) }\end{array}$ & $\begin{array}{c}\text { Number of } \\
\text { branchesl } \\
\text { plant }\end{array}$ & $\begin{array}{c}\text { Dry } \\
\text { weight of } \\
\text { foliage } \\
\text { (g) / plant }\end{array}$ & $\begin{array}{l}\text { Plant } \\
\text { height } \\
(\mathrm{cm})\end{array}$ & $\left|\begin{array}{c}\text { Number of } \\
\text { branches } I \\
\text { plant }\end{array}\right|$ & $\begin{array}{l}\text { Dry weight } \\
\text { of foliage } \\
\text { (g) / plant }\end{array}$ \\
\hline \multirow{3}{*}{$\begin{array}{l}1^{\text {st }} \text { date } \\
\text { at } 15 / 7\end{array}$} & $100 \%$ & 55.2 & 5.7 & 34.983 & 53.3 & 6.0 & 33.827 \\
\hline & $80 \%$ & 50.7 & 6.4 & 32.000 & 51.3 & 6.4 & 32.727 \\
\hline & $60 \%$ & 47.9 & 5.4 & 28.020 & 47.7 & 5.3 & 28.640 \\
\hline \multicolumn{2}{|r|}{ Mean } & 51.3 & 5.8 & 31.668 & 50.8 & 5.9 & 31.731 \\
\hline \multirow{3}{*}{$\begin{array}{c}2^{\text {nd }} \text { date } \\
\text { At } 7 / 8\end{array}$} & $100 \%$ & 45.6 & 4.9 & 26.160 & 46.2 & 4.9 & 26.843 \\
\hline & $80 \%$ & 42.5 & 4.6 & 24.060 & 42.5 & 4.8 & 25.687 \\
\hline & $60 \%$ & 38.6 & 4.4 & 20.953 & 39.1 & 4.7 & 21.510 \\
\hline \multicolumn{2}{|r|}{ Mean } & 42.2 & 4.6 & 23.724 & 42.6 & 4.8 & 24.680 \\
\hline \multirow{3}{*}{$\begin{array}{l}3^{\text {rd date }} \\
\text { at } 28 / 8\end{array}$} & $100 \%$ & 36.0 & 4.7 & 20.793 & 36.9 & 4.8 & 21.673 \\
\hline & $80 \%$ & 33.6 & 4.5 & 19.713 & 34.2 & 4.7 & 20.380 \\
\hline & $60 \%$ & 31.4 & 4.3 & 17.533 & 32.8 & 4.4 & 16.510 \\
\hline \multicolumn{2}{|r|}{ Mean } & 33.6 & 4.5 & 19.347 & 34.7 & 4.6 & 19.521 \\
\hline \multirow{3}{*}{ Average } & $100 \%$ & 45.6 & 5.1 & 27.312 & 45.5 & 5.2 & 27.448 \\
\hline & $80 \%$ & 42.3 & 5.2 & 25.258 & 42.7 & 5.3 & 26.264 \\
\hline & $60 \%$ & 39.3 & 4.7 & 22.169 & 39.9 & 4.8 & 22.220 \\
\hline \multirow{3}{*}{$\begin{array}{c}\text { L S D at } \\
0.05 \%\end{array}$} & Planting dates & 4.8 & 0.40 & 3.817 & 3.7 & 0.36 & 3.496 \\
\hline & $\begin{array}{l}\text { Irrigation schedule } \\
\text { regimes (\%) }\end{array}$ & 3.9 & 0.31 & 2.443 & 4.3 & 0.24 & 2.932 \\
\hline & Interactions & 3.6 & 0.35 & 2.729 & 4.8 & 0.27 & 3.276 \\
\hline
\end{tabular}


2-Yield and its components:

2-1-Effect of planting dates:

The results at Tables, 4 and 5 illustrate that the effect of planting dates on dry seeds yield and its components measurements as well as water use efficiency indicated that, the superior values were obtained from the $1^{\text {st }}$ planting date which induced significantly increases of all traits as compared with the $2^{\text {nd }}$ and the $3^{\text {rd }}$ planting dates, respectively. In this connection, the dry seeds yield of cowpea plants is the result of many interacting of yield components such as, number of dry podsl plant, number of dry seeds/ pod, weight of dry pods/ plant and weight of 100 dry seeds, whereas this component values showed significant increases which it reflected on the total dry seed yield.

Table 4: Effect of planting dates, irrigation schedule regimes and their interactions on dry pod length, dry pod diameter, dry pod weight and number of dry seeds/ pod of the cowpea plants during the two fall seasons of 2016 and 2017

\begin{tabular}{|c|c|c|c|c|c|c|c|c|c|}
\hline \multirow{2}{*}{$\begin{array}{c}\text { Effect of } \\
\text { planting } \\
\text { dates }\end{array}$} & \multirow[b]{2}{*}{$\begin{array}{c}\text { Irrigation } \\
\text { schedule } \\
\text { regimes (\%) }\end{array}$} & \multicolumn{4}{|c|}{2016} & \multicolumn{4}{|c|}{2017} \\
\hline & & $\begin{array}{c}\text { Dry pod } \\
\text { length } \\
(\mathrm{cm})\end{array}$ & $\begin{array}{c}\text { Dry pod } \\
\text { diameter } \\
\text { (cm) }\end{array}$ & $\begin{array}{c}\text { Dry pod } \\
\text { weight } \\
\text { (g) }\end{array}$ & \begin{tabular}{|c} 
No. of \\
dry \\
seeds/ \\
pod
\end{tabular} & $\begin{array}{c}\text { Dry pod } \\
\text { length } \\
(\mathrm{cm})\end{array}$ & $\begin{array}{c}\text { Dry pod } \\
\text { diameter } \\
(\mathrm{cm})\end{array}$ & $\begin{array}{c}\text { Dry pod } \\
\text { weight } \\
\text { (g) }\end{array}$ & $\begin{array}{l}\text { No. of } \\
\text { dry } \\
\text { seeds/ } \\
\text { pod }\end{array}$ \\
\hline \multirow{3}{*}{$\begin{array}{l}1^{\text {st }} \text { date } \\
\text { at } 15 / 7\end{array}$} & $100 \%$ & 13.1 & 0.54 & 2.137 & 9.5 & 13.0 & 0.52 & 2.063 & 9.5 \\
\hline & $80 \%$ & 13.3 & 0.58 & 2.410 & 9.7 & 13.5 & 0.54 & 2.240 & 9.7 \\
\hline & $60 \%$ & 12.6 & 0.51 & 2.047 & 9.0 & 12.7 & 0.46 & 1.917 & 9.1 \\
\hline \multicolumn{2}{|r|}{ Mean } & 13.0 & 0.54 & 2.198 & 9.4 & 13.1 & 0.51 & 2.073 & 9.4 \\
\hline \multirow{3}{*}{$\begin{array}{c}2^{\text {nd }} \text { date } \\
\text { at } 7 / 8\end{array}$} & $100 \%$ & 12.7 & 0.47 & 1.850 & 8.2 & 12.7 & 0.46 & 1.767 & 7.8 \\
\hline & $80 \%$ & 12.6 & 0.46 & 1.620 & 7.9 & 12.4 & 0.44 & 1.657 & 7.5 \\
\hline & $60 \%$ & 12.2 & 0.42 & 1.420 & 7.6 & 12.2 & 0.43 & 1.343 & 7.5 \\
\hline \multicolumn{2}{|r|}{ Mean } & 12.5 & 0.45 & 1.630 & 7.9 & 12.4 & 0.44 & 1.589 & 7.6 \\
\hline \multirow{3}{*}{$\begin{array}{l}3^{\text {rd }} \text { date } \\
\text { at } 28 / 8\end{array}$} & $100 \%$ & 11.5 & 0.42 & 1.627 & 7.8 & 11.5 & 0.39 & 1.557 & 7.4 \\
\hline & $80 \%$ & 11.3 & 0.41 & 1.457 & 7.4 & 11.3 & 0.39 & 1.447 & 7.2 \\
\hline & $60 \%$ & 11.2 & 0.39 & 1.317 & 7.2 & 11.1 & 0.37 & 1.423 & 7.1 \\
\hline \multicolumn{2}{|c|}{ Mean } & 11.3 & 0.41 & 1.467 & 7.5 & 11.3 & 0.38 & 1.476 & 7.2 \\
\hline \multirow{3}{*}{ Average } & $100 \%$ & 12.4 & 0.48 & 1.871 & 8.5 & 12.4 & 0.46 & 1.796 & 8.2 \\
\hline & $80 \%$ & 12.4 & 0.48 & 1.829 & 8.4 & 12.4 & 0.46 & 1.781 & 8.1 \\
\hline & $60 \%$ & 12.0 & 0.44 & 1.594 & 8.0 & 12.0 & 0.42 & 1.561 & 7.9 \\
\hline \multirow{3}{*}{$\begin{array}{c}\text { L S D at } \\
0.05 \%\end{array}$} & Planting dates & 0.41 & 0.05 & 0.39 & 0.59 & 0.45 & 0.07 & 0.34 & 0.42 \\
\hline & $\begin{array}{l}\text { Irrigation } \\
\text { schedule } \\
\text { regimes (\%) }\end{array}$ & 0.17 & N S & 0.16 & 0.39 & 0.21 & NS & 0.11 & N S \\
\hline & Interactions & 0.24 & 0.07 & 0.34 & 0.44 & 0.32 & 0.10 & 0.37 & 0.49 \\
\hline
\end{tabular}


Table 5: Effect of planting dates, irrigation schedule regimes and their interactions on weight of $\mathbf{1 0 0}$ dry seeds, number of dry pods/ plant, weight of dry pods/ plant, total dry seed yield and water use efficiency of the cowpea plants during the two fall seasons of 2016 and 2017

\begin{tabular}{|c|c|c|c|c|c|c|c|c|c|c|c|}
\hline \multirow{2}{*}{$\begin{array}{l}\text { Effect of } \\
\text { planting } \\
\text { dates }\end{array}$} & \multirow[b]{2}{*}{$\begin{array}{l}\text { Irrigation } \\
\text { schedule } \\
\text { regimes (\%) }\end{array}$} & \multicolumn{5}{|c|}{2016} & \multicolumn{5}{|c|}{2017} \\
\hline & & $\begin{array}{l}\text { weight } \\
\text { of } 100 \\
\text { dry } \\
\text { seeds } \\
\text { (g) }\end{array}$ & $\begin{array}{l}\text { No. } \\
\text { of } \\
\text { dry } \\
\text { podsI } \\
\text { plant }\end{array}$ & $\begin{array}{c}\text { weight } \\
\text { of dry } \\
\text { podsl } \\
\text { plant } \\
\text { (g) }\end{array}$ & {$\left[\begin{array}{c}\text { Total dry } \\
\text { seed } \\
\text { yield } \\
\text { (Ton/fed.) }\end{array}\right)$ e } & $\begin{array}{c}\text { Water } \\
\text { use } \\
\text { efficiency }\end{array}$ & $\begin{array}{c}\text { weight } \\
\text { of } 100 \\
\text { dry } \\
\text { seeds } \\
\text { (g) }\end{array}$ & $\begin{array}{c}\text { No. } \\
\text { of } \\
\text { dry } \\
\text { podsl } \\
\text { plant }\end{array}$ & $\begin{array}{c}\text { Weight } \\
\text { of dry } \\
\text { podsl } \\
\text { plant } \\
\text { (g) }\end{array}$ & $\begin{array}{l}\text { Total dry } \\
\text { seed } \\
\text { yield } \\
\text { (Ton/fed.) }\end{array}$ & $\begin{array}{c}\text { Water } \\
\text { use } \\
\text { efficiency }\end{array}$ \\
\hline \multirow{3}{*}{$\begin{array}{l}1^{\text {st }} \text { date } \\
\text { at } 15 / 7\end{array}$} & $100 \%$ & 16.750 & 31.7 & 63.333 & 0.950 & 0.633 & 17.123 & 29.1 & 60.173 & 0.908 & 0.605 \\
\hline & $80 \%$ & 17.390 & 35.3 & 70.620 & 1.109 & 0.924 & 17.167 & 33.8 & 65.593 & 1.087 & 0.906 \\
\hline & $60 \%$ & 16.527 & 27.4 & 54.693 & 0.825 & 0.917 & 16.457 & 27.0 & 53.980 & 0.800 & 0.889 \\
\hline \multicolumn{2}{|c|}{ Mean } & 16.889 & 31.5 & 62.882 & 0.961 & 0.825 & 16.916 & 29.6 & 59.916 & 0.932 & 0.800 \\
\hline \multirow{3}{*}{$\begin{array}{c}2^{\text {nd }} \text { date } \\
\text { at } 7 / 8\end{array}$} & $100 \%$ & 15.193 & 27.7 & 49.843 & 0.707 & 0.471 & 15.110 & 25.5 & 47.137 & 0.737 & 0.491 \\
\hline & $80 \%$ & 14.580 & 26.5 & 47.603 & 0.661 & 0.551 & 14.317 & 24.9 & 45.367 & 0.680 & 0.567 \\
\hline & $60 \%$ & 13.913 & 25.0 & 44.713 & 0.613 & 0.681 & 13.397 & 24.4 & 43.830 & 0.622 & 0.691 \\
\hline \multicolumn{2}{|c|}{ Mean } & 14.562 & 26.4 & 47.387 & 0.660 & 0.568 & 14.274 & 25.0 & 45.444 & 0.680 & 0.583 \\
\hline \multirow{3}{*}{$\begin{array}{l}3^{\text {rd }} \text { date } \\
\text { at } 28 / 8\end{array}$} & $100 \%$ & 13.690 & 24.5 & 37.943 & 0.660 & 0.440 & 13.220 & 23.3 & 34.937 & 0.670 & 0.447 \\
\hline & $80 \%$ & 13.117 & 22.9 & 35.400 & 0.625 & 0.521 & 12.883 & 21.8 & 32.633 & 0.607 & 0.506 \\
\hline & $60 \%$ & 12.453 & 21.3 & 32.403 & 0.600 & 0.667 & 12.473 & 19.8 & 29.727 & 0.586 & 0.651 \\
\hline \multicolumn{2}{|c|}{ Mean } & 13.087 & 22.9 & 35.249 & 0.628 & 0.543 & 12.859 & 21.6 & 32.432 & 0.621 & 0.535 \\
\hline \multirow{3}{*}{ Average } & $100 \%$ & 15.211 & 27.9 & 50.373 & 0.772 & 0.515 & 15.151 & 26.0 & 47.416 & 0.771 & 0.514 \\
\hline & $80 \%$ & 15.029 & 28.2 & 51.208 & 0.798 & 0.665 & 14.789 & 26.5 & 47.864 & 0.791 & 0.660 \\
\hline & $60 \%$ & 14.298 & 24.6 & 43.937 & 0.680 & 0.755 & 14.109 & 23.7 & 42.512 & 0.669 & 0.743 \\
\hline \multirow{3}{*}{$\begin{array}{c}\text { L S D at } \\
0.05 \%\end{array}$} & $\begin{array}{c}\text { Planting } \\
\text { dates }\end{array}$ & 0.454 & 2.63 & 7.573 & 0.091 & 0.080 & 0.363 & 3.3 & 7.373 & 0.111 & 0.097 \\
\hline & $\begin{array}{c}\text { Irrigation } \\
\text { schedule } \\
\text { regimes (\%) }\end{array}$ & 0.454 & 1.92 & 3.610 & 0.074 & 0.068 & 0.638 & 2.7 & 2.653 & 0.091 & 0.081 \\
\hline & Interactions & 0.507 & 2.15 & 4.043 & 0.132 & 0.125 & 0.713 & 3.0 & 2.964 & 0.160 & 0.151 \\
\hline
\end{tabular}

On other wise, the highest reduction of dry seeds yield were obtained from the treatment of the late planting date and this may be attribute to the low soil temperatures which its affected the seed germination poor and consequently resulted in lowered plant population and also cause abscission of the flowers and small pod abortion led to reduce in the dry seeds yield that may be caused by early low temperature at night or lack of enough time for pods filling stage and production, this could lead to loss in grain yield (Akande et al., 2012). These results reinforced with Ezeaku et al. (2015) they pointed out that the $1^{\text {st }}$ planting date at $24^{\text {th }}$ of July gave significantly increased the weight of 100 dry seeds, number of pods per plant, number of dry seeds per pod, pod length and yield/ hectare as compared with that the $2^{\text {nd }}$ planting date at the $12^{\text {th }}$ of September which gave the lowest of all the previous traits of the cowpea plants. 
2-2-Effect of water schedule regimes:

Data recorded in the same Tables, 4 and 5 indicate that the effect of water schedule regimes i.e. $100 \%, 80 \%$ and $60 \%$ from the cowpea plants irrigation requirements/ fed. on dry seeds yield, its components and water use efficiency measurements the obtained data showed that, the full irrigation treatment $(100 \%$ l fed.) lead to the maximum increases in dry pod weight, number of dry seeds/ pod and weight of 100 dry seeds. While, the cowpea plants irrigated with the moderate irrigation treatment $(80 \% /$ fed.) lead to the maximum increases on the dry seeds yield, number of dry pods/ plant and weight of dry pods/ plant in the $1^{\text {st }}$ and the $2^{\text {nd }}$ season, respectively as well as no significant different was obtained between the 100 and $80 \% /$ from the cowpea plants irrigation requirements/ fed. Water use efficiency significantly increased with irrigation plants with $60 \%$ from water requirements/ fed. followed with plant irrigated with $80 \%$ and $100 \%$ fed.

On the contrary, the lowest results recorded in dry pod characters and the dry seeds yield were obtained when the plants were irrigated with the lowest water amount i.e. $60 \%$ from the cowpea plants irrigation requirementsl fed. as compared with the plants which irrigated with the two other water schedule regimes during the two fall seasons, respectively. The reduction in the dry seeds yield and its components as a result of increment the water stress levels may by due to the negative effect of water stress on plant height, number of branches, dry weight per plant, pod weight and number of pods as discussed before (Tables 3, 4 and 5 ). In this orientation, Abdul-Jaleel et al. (2009) indicated that water deficit is one of the major a biotic stress, which adversely affects the plant growth and yield. These changes are mainly related to the alteration of metabolic functions, conditions due to increasing the rate of flowers abscission \%, pod abortion such as the reduction in the synthesis of photosynthesis pigments, thereby these changes in the amount of photosynthetic pigments are closely associated to plant biomass yield.

In addition, it can explain the superiority effects of applied water regime i.e. $80 \%$ from the cowpea plants irrigation requirements/ fed. which induced significantly increased of the dry seed yield and its components, may be due to increase volume applied water irrigation at $100 \%$ from the cowpea plants irrigation requirementsl fed. means, decreasing in the concentration of nutrients in the root zone and also, applied $80 \% /$ fed. is the best case or suitable conditions, these conditions decreased from water stress or drought stress and also, achieved excellent distribution for nutrients inside root zone. While at $\mathbf{1 0 0} \%$ it can get the lowest water stress but not achieve excellent distribution for nutrients inside root zone because of increasing leaching rate with increasing volume of applied water (Bakry et al., 2013). The results also are in conformity with the findings with Dalia et al. (2017) which mentioned that irrigation the cowpea plants at $70 \%$ of available water of the available soil moisture produced the highest mean values of the 100 seed weight, seed yield per plant and seed yield ( $\mathrm{kg} / \mathrm{hectare}$ ) while, the lowest previous characters as well as the highest water use efficiency recorded when irrigation was applied at $30 \%$.

\section{2-3-Effect of the interactions:}

Regarding to the effect of the interactions between planting dates and water schedule regimes of the cowpea plants on dry seeds yield, its components and water use efficiency, the results at the same Tables, 4 and 5 indicate that the $1^{\text {st }}$ planting date at the 
middle of July as well as irrigated the cowpea plants with the moderate irrigation regime i.e. $80 \%$. gave the highest means values of dry pod characters, the dry seeds yield (1.109 and 1.087 ton/ fed.) comparing with the other interactions i.e. the full irrigation regime i.e. $100 \%$ (0.950 and 0.908 ton/ fed.) and the severe stress irrigation regime i.e. $60 \%(0.825$ and 0.800 ton/ fed.) from the cowpea plants irrigation requirements/ fed. On the other hand, the best water use efficiency obtained with the moderate irrigation regime i.e. $80 \%$ ( 0.924 and $0.906 \mathrm{Kg}$ yield $/ \mathrm{m}^{3}$ water) followed with severe stress irrigation regime i.e. $60 \%\left(0.917\right.$ and $0.889 \mathrm{Kg}$ yield $/ \mathrm{m}^{3}$ water $)$ as well as full irrigation regime i.e. $100 \%$ $\left(0.633\right.$ and $0.605 \mathrm{Kg}$ yield $/ \mathrm{m}^{3}$ water $)$ in the $1^{\text {st }}$ and the $2^{\text {nd }}$ seasons, respectively. On the contrast, the lowest records on the dry seeds yield and its components were obtained with the interactions between the $3^{\text {rd }}$ planting date at $28^{\text {th }}$ of August (late season) and irrigation the cowpea plants with severe stress irrigation regime i.e. $60 \%$ from the cowpea plants irrigation requirements/ fed. in the $1^{\text {st }}$ and the $2^{\text {nd }}$ season, respectively. Moreover, the increases in the cowpea dry seed yield and its components can be explained by the significant increases due to the greatest values of the vegetative growth characters as mentioned before in Table, 3 during the two growing fall seasons.

\section{3-Chemical composition of the cowpea leaves and dry seeds: \\ 3-1-Effect of planting dates:}

Data presented at Tables, 6 and 7 on the total chlorophyll contents in the fresh leaves, the proline contents in the dry leaves, the protein, nitrogen, phosphorus and potassium in the dry seeds indicate that, the $1^{\text {st }}$ planting date significantly increased all the previous traits as compared with the $2^{\text {nd }}$ and the $3^{\text {rd }}$ planting dates, respectively. These results coincided with those reported by Heba et al. (2015) who found that sowing snap bean in the first sowing date at $1^{\text {st }}$ of October gave the highest significant values of nitrogen, phosphorus and potassium contents in snap bean leaves as well as portion in its pods as compared with the $2^{\text {nd }}$ sowing one at $16^{\text {th }}$ of the same month.

3-2-Effect of water schedule regimes:

Regarding to the results of the previous chemical composition, data in the same Tables, 6 and 7 as affected by different water schedule regimes show that the superiority values of the total chlorophyll contents in the fresh leaves occurred when the cowpea plants received the complete irrigation treatment (100 \%l fed.). whereas, proline contents in the dry foliage as well as protein, nitrogen and potassium in the dry seeds were increased as compared with an increasing water deficient from $100 \%$ to $80 \%$ from the cowpea plants irrigation requirements/ fed. without any significant differences between the previous two schedule regimes. The highest percent of proline of cowpea dry leaves which achieved when the plants were irrigated with the middle water regime treatment i.e. $80 \%$ followed with $100 \% /$ fed. but under the highest severe of water stress ( $60 \% /$ fed.) proline tended to decrease. These results are further supported by Amira (2014) who reported that the most decrease in the concentration of photosynthetic pigments i.e. total chlorophyll, as a result of drought stress which reduced the uptake of nitrogen, phosphorus and potassium contents \%, it's occurred under the condition of $40 \%$ (field capacity) of soybean plants. Geeth and Abdel-Aziz (2017) generalized that subjected the snap bean plants to three water levels $(100,80$ and $60 \%$ of from the snap bean plants irrigation requirements $I$ 
fed.) which led to significant increase in total chlorophyll content in the fresh leaves, protein contents in the pods, nitrogen, phosphorus and potassium \% in the dry leaves. It was found also that the highest reduction in the previous characters of pods quality pronounces in the level of $60 \%$ from water requirements/ fed.

\section{3-3-Effect of the interactions:}

It noticed significant interactions effects between of the two studied factors i.e. planting dates and water schedule regimes of the cowpea plants on total chlorophyll contents in fresh leaves, proline contents in dry leaves as well as protein, nitrogen, phosphorus and potassium contents in cowpea dry seeds as shown in the same Tables, 6 and 7 . The pronounced interactions on the previous characters were obtained with the interaction between the $1^{\text {st }}$ planting date at the middle of July as well as irrigation cowpea plants with the moderate irrigation regime i.e. $80 \%$ from the cowpea plants irrigation requirements/ fed. as compared with the rest of the two interactions.

Table 6: Effect of planting dates, irrigation schedule regimes and their interactions on the total chlorophyll contents in the fresh leaves, proline contents of the dry leaves and protein contents of the cowpea dry seeds during the two fall seasons of 2016 and 2017

\begin{tabular}{|c|c|c|c|c|c|c|c|}
\hline \multirow{2}{*}{$\begin{array}{l}\text { Effect of } \\
\text { planting } \\
\text { dates }\end{array}$} & \multirow[b]{2}{*}{$\begin{array}{l}\text { Irrigation } \\
\text { schedule } \\
\text { regimes (\%) }\end{array}$} & \multicolumn{3}{|c|}{2016} & \multicolumn{3}{|c|}{2017} \\
\hline & & $\begin{array}{c}\text { Total } \\
\text { chlorophyll } \\
\text { mg/ } 100 \mathrm{~g} \\
\text { (F. W.) }\end{array}$ & $\begin{array}{l}\text { Proline } \\
(\mathrm{mg} / \mathrm{g})\end{array}$ & $\begin{array}{l}\text { Protein } \\
\text { (\%) }\end{array}$ & \begin{tabular}{|c|} 
Total \\
chlorophyll \\
mg/ $100 \mathrm{~g}$ \\
(F. W.) \\
\end{tabular} & $\begin{array}{l}\text { Proline } \\
(\mathrm{mg} / \mathrm{g})\end{array}$ & $\begin{array}{l}\text { Protein } \\
(\%)\end{array}$ \\
\hline \multirow{3}{*}{$\begin{array}{l}1^{\text {st }} \text { date } \\
\text { at } 15 / 7\end{array}$} & $100 \%$ & 139.6 & 0.33 & 21.7 & 140.2 & 0.34 & 21.4 \\
\hline & $80 \%$ & 149.4 & 0.39 & 22.9 & 150.2 & 0.40 & 22.6 \\
\hline & $60 \%$ & 131.1 & 0.31 & 20.6 & 138.4 & 0.32 & 20.8 \\
\hline \multicolumn{2}{|c|}{ Mean } & 140.0 & 0.34 & 21.8 & 142.9 & 0.35 & 21.6 \\
\hline \multirow{3}{*}{$\begin{array}{c}2^{\text {nd }} \text { date } \\
\text { at } 7 / 8\end{array}$} & $100 \%$ & 141.3 & 0.29 & 20.6 & 138.9 & 0.31 & 20.4 \\
\hline & $80 \%$ & 131.1 & 0.28 & 20.3 & 130.2 & 0.29 & 20.2 \\
\hline & $60 \%$ & 119.3 & 0.24 & 20.0 & 116.8 & 0.26 & 20.0 \\
\hline \multicolumn{2}{|c|}{ Mean } & 130.6 & 0.27 & 20.6 & 128.6 & 0.29 & 20.2 \\
\hline \multirow{3}{*}{$\begin{array}{l}3^{\text {rd }} \text { date } \\
\text { at } 28 / 8\end{array}$} & $100 \%$ & 132.4 & 0.25 & 20.4 & 126.7 & 0.26 & 20.2 \\
\hline & $80 \%$ & 120.8 & 0.23 & 20.3 & 116.2 & 0.24 & 20.1 \\
\hline & $60 \%$ & 109.0 & 0.20 & 20.0 & 108.5 & 0.20 & 20.0 \\
\hline \multicolumn{2}{|c|}{ Mean } & 120.8 & 0.23 & 20.2 & 117.2 & 0.23 & 20.1 \\
\hline \multirow{3}{*}{ Average } & $100 \%$ & 137.8 & 0.29 & 20.9 & 135.3 & 0.30 & 20.7 \\
\hline & $80 \%$ & 133.8 & 0.30 & 21.2 & 132.2 & 0.31 & 21.0 \\
\hline & $60 \%$ & 119.8 & 0.25 & 20.2 & 121.2 & 0.26 & 20.3 \\
\hline \multirow{3}{*}{$\begin{array}{c}\text { L S D at } \\
0.05 \%\end{array}$} & Planting dates & 11.02 & 0.06 & 0.54 & 13.92 & 0.07 & 0.41 \\
\hline & $\begin{array}{c}\text { Irrigation } \\
\text { regimes (\%) }\end{array}$ & 4.77 & 0.09 & 0.24 & 4.44 & 0.08 & 0.20 \\
\hline & Interactions & 5.32 & 0.10 & 0.27 & 4.96 & 0.09 & 0.23 \\
\hline
\end{tabular}


Table 7: Effect of planting dates, irrigation schedule regimes and their interactions on nitrogen, phosphorus and potassium contents of the cowpea dry seeds during the two fall seasons of 2016 and 2017

\begin{tabular}{|c|c|c|c|c|c|c|c|}
\hline \multirow{2}{*}{$\begin{array}{c}\text { Effect of } \\
\text { planting } \\
\text { dates }\end{array}$} & \multirow{2}{*}{$\begin{array}{l}\text { Irrigation } \\
\text { schedule } \\
\text { regimes (\%) }\end{array}$} & \multicolumn{3}{|c|}{2016} & \multicolumn{3}{|c|}{2017} \\
\hline & & \begin{tabular}{|c|}
$\begin{array}{c}\text { Nitrogen } \\
\text { (\%) }\end{array}$ \\
\end{tabular} & $\begin{array}{c}\text { Phosphorus } \\
\text { (\%) }\end{array}$ & $\begin{array}{c}\text { Potassium } \\
\text { (\%) }\end{array}$ & \begin{tabular}{|c}
$\begin{array}{c}\text { Nitrogen } \\
(\%)\end{array}$ \\
\end{tabular} & \begin{tabular}{|c} 
Phosphorus \\
(\%)
\end{tabular} & $\begin{array}{c}\text { Potassium } \\
\text { (\%) }\end{array}$ \\
\hline \multirow{3}{*}{$\begin{array}{l}1^{\text {st }} \text { date } \\
\text { at } 15 / 7\end{array}$} & $100 \%$ & 3.47 & 0.240 & 1.923 & 3.43 & 0.243 & 1.963 \\
\hline & $80 \%$ & 3.67 & 0.247 & 2.327 & 3.61 & 0.263 & 2.273 \\
\hline & $60 \%$ & 3.29 & 0.227 & 1.847 & 3.33 & 0.240 & 1.830 \\
\hline \multicolumn{2}{|c|}{ Mean } & 3.48 & 0.238 & 2.032 & 3.47 & 0.249 & 2.022 \\
\hline \multirow{3}{*}{$\begin{array}{c}2^{\text {nd }} \text { date } \\
\text { at } 7 / 8\end{array}$} & $100 \%$ & 3.29 & 0.223 & 1.743 & 3.26 & 0.227 & 1.770 \\
\hline & $80 \%$ & 3.25 & 0.207 & 1.640 & 3.23 & 0.217 & 1.667 \\
\hline & $60 \%$ & 3.20 & 0.207 & 1.533 & 3.20 & 0.207 & 1.553 \\
\hline \multicolumn{2}{|c|}{ Mean } & 3.25 & 0.212 & 1.639 & 3.23 & 0.217 & 1.663 \\
\hline \multirow{3}{*}{$\begin{array}{l}3^{\text {rd d date }} \\
\text { at } 28 / 8\end{array}$} & $100 \%$ & 3.26 & 0.203 & 1.413 & 3.23 & 0.200 & 1.450 \\
\hline & $80 \%$ & 3.24 & 0.193 & 1.453 & 3.21 & 0.183 & 1.427 \\
\hline & $60 \%$ & 3.20 & 0.170 & 1.367 & 3.15 & 0.170 & 1.383 \\
\hline \multicolumn{2}{|c|}{ Mean } & 3.23 & 0.189 & 1.411 & 3.20 & 0.184 & 1.420 \\
\hline \multirow{3}{*}{ Average } & $100 \%$ & 3.34 & 0.222 & 1.693 & 3.30 & 0.224 & 1.728 \\
\hline & $80 \%$ & 3.39 & 0.216 & 1.807 & 3.35 & 0.221 & 1.789 \\
\hline & $60 \%$ & 3.23 & 0.201 & 1.582 & 3.23 & 0.206 & 1.589 \\
\hline \multirow{3}{*}{$\begin{array}{c}\text { L S D at } \\
0.05 \%\end{array}$} & Planting dates & 0.09 & 0.04 & 0.09 & 0.06 & 0.06 & 0.11 \\
\hline & $\begin{array}{c}\text { Irrigation } \\
\text { schedule } \\
\text { regimes (\%) }\end{array}$ & 0.05 & N S & 0.12 & 0.08 & N S & 0.09 \\
\hline & Interactions & 0.05 & 0.06 & 0.13 & 0.07 & 0.09 & 0.10 \\
\hline
\end{tabular}

\section{Conclusions}

It could be concluded that, under the conditions of this investigation, it can recommended by cultivate, the cowpea plants Kaha $1 \mathrm{cv}$. in the first sowing date i.e. the middle of July as well as irrigation the plants by $80 \%$ from plants irrigation requirements/ fed. to obtain superior effects of the vegetative growth character, dry seed yield (ton/ fed.) and its components, water use efficiency, the best dry seed quality as well as it is very important for saving a part of the irrigation water, which calculated by about $20 \%$ especially under the condition of the limited water resources nowadays for the newly reclaimed areas in Egypt.

\section{REFERENCES}

Abdel-Raouf, R. E. (2015). New design for drip irrigation system to maximize water and fertilizers use efficiency. Eighteenth International Water Technology Conference, IWTC18 : 250 $-263$. 
Abdul-Jaleel, C., P. Manivannan, A. Wahid, M. Farooq, H. J. Al-Juburi, R. Somasundaram and $R$. Panneerselvam (2009). Drought stress in plants: A Review on morphological characteristics and pigments composition. Int. J. Agric. Biol. 11: 100-105.

Akande, S. R., S. A. Olakojo, S. A. Ajayi, O. F. Owolade, J. A. Adetumbi, O. N. Adeniyan and B. A. Ogunbodede (2012). Planting date affects on cowpea seed yield and quality at southern guinea Savanna of Nigeria. Proofs. 34: 79 - 88.

Amira, M. S. A. (2014). Effect of ascorbic acid antioxidant on soybean (Glycine max L.) plants grown under water stress conditions. Int. J. Adv. Res. Biol., Sci. 1 (6):189-205.

Bakry, A. B., R. E. Abdelraouf and A. Ahmed (2013). Effect of drought stress and ascorbic acid foliar application on productivity and irrigation water use efficiency of wheat under newly reclaimed sandy soil. Elixir Agric. 57 A. 14398-14403.

Belay, F., A. Gebreslasie and H. Meresa (2017). Agronomic performance evaluation of cowpea [Vigna unguiculata (L.) Walp] varieties in Abergelle District, Northern Ethiopia, J. Plant Breed. Crop Sci., 139-143.

Bremner, J. M. and C. S. Mulvaney (1982). Total nitrogen. In: Pag, A. L., R. H. Miller and D. R. Keeny (Ed.). Methods of Soil Analysis. Part 2, Amer. Soc. Agron. Madison, W. I. USA, 595-624.

Bricker, B. (1991). MSTATC: A micro computer program from the design management and analysis of agronomic research experiments. Michigan State Univ. USA.

Dalia, M. T. N., H. M. El-Aref and N. M. K. Roshdy (2017). Impact of irrigation water deficit and foliar application with salicylic acid on the productivity of two cowpea cultivars. Egypt. J. Hort., 44 (1): 75- 90.

Dugje, I. Y., L. O. Omoigui, F. Ekeleme, A. Y. Kamara and H. Ajeigbe (2009). Farmers' Guide to Cowpea Production in West Africa. IITA: Ibadan, Nigeria. 20.

Ezeaku, E., B. N. Mbah and K. P. Baiyeri (2015). Planting date and cultivar effects on growth and yield performance of cowpea (Vigna unguiculata (L.) Walp). Afr. J. Plant Sci., 9 (11): 439-448.

Farooq, M., M. Hussain, Abdul-Wahid and K. H. M. Siddique (2012) Drought Stress in Plants: An Overview.pp.1-5. In: R. Aroca (ed.), plant responses to drought stress, DOI: 10.1007/978-3642-32653-0_1, Springer-Verlag Berlin Heidelberg.

Food and Agriculture Organization of the United Nations (FAO) (2013). Grassland Index. A Searchable catalogue of grass and forage legumes. FAO, Rome, Italy.

Geeth, R. H. M. and M. A. Abdel-Aziz (2017). Response growth and productivity of snap bean (Phaseolus vulgaris L.) plants to organic manure fertilization, irrigation regimes and foliar spraying with ascorbic acid under newly reclaimed soil condition. Menoufia J. Plant Prod., 2 (8): 359 381.

Heba, S. A., S. M. Shehata, A. M. ElGizawy, A. Abou El-Yazied and S. M. Adam (2015). Snap bean response to salicylic acid and putrescine used separately and jointly under two sowing dates. Middle East J. Applied Sci. 5 | Issue :04 | Oct.-Dec., 12111221.

Horneck, D. A. and D. Hanson (1998). Determination of potassium and sodium by Flam Emission 
Spectrophotometry. In Handbook of Referance Methods for plant analysis. Kalra, Y. P. (Ed.):153-155.

Jackson, M. L. (1973). Soil Chemical Analysis. Prentic-Hall, Indian.

Kelly, J. D. and F. A. Bliss (1975). Heritability estimates of percentage seed protein and available methionine and correlations with yield in dry bean. Crop Sci. 15: 753-757.

Nagata, M. and I. Yamashita (1992). Simple method for simultaneous determination of chlorophyll and carotenoids in tomato fruit. J. Japan Soc. Food Sci., Technol. 39: 928-932.

Olsen, S. R. and L. E. Sommers (1982). Phosphorus. In: Page, R. H. Miller and D. R. Keeney (Ed.). Methods of Soil Analysis. Part 2 Amer. Soc. Agron. Madison, W. I. USA: 403-430.
Piper, G. S. (1947). Soil and Plant Analysis. Interscience Publishers, Inc. NY, 368.

Rahil, M. H. and A. Qanadillo (2015). Effects of different irrigation regimes on yield and water use efficiency of cucumber crop. Agric., Water Manag. 148, 10 - 15.

Ruiz-Lozano, J., R. Porcel, C. Azco'n and R. Aroca (2012). Regulation by arbuscular mycorrhizae of the integrated physiological response to salinity in plants: new challenges in physiological and molecular studies. J. Exp. Bot. 63(11): 4033 - 4044.

Troll, W. and J. Lindsley (1955). A photometric method for determination of proline. J. Biol., Chem., 215:655660. 
تأثير مواعيد الزراعه ومعدلات الرى بالتنقيط على النمو والمحصول ومكوناته فى نباتات اللوبيا تحت ظروف الأرض الرملية

\author{
ربيع حسن محمد غيث \\ قسم بحوث الخضر ذاتية التلقيح، معهد بحوث البساتين - مركز البحوث الزراعية- الجيزة- مصر
}

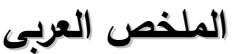

أجربت تجربتان حقليتان بمزرعه خاصة بمنطقة بنى مزار شمال محافظة المنيا فى الموسم النيلى لعامى 2016 -

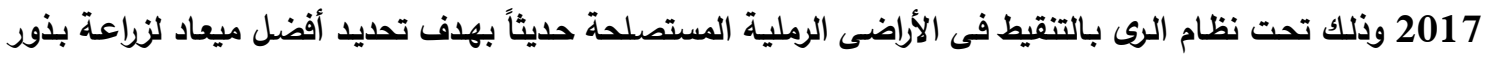

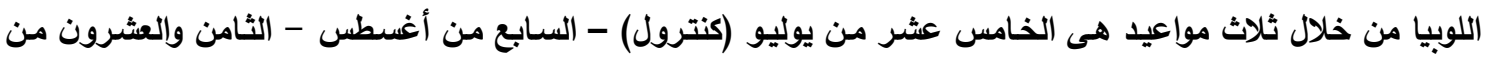

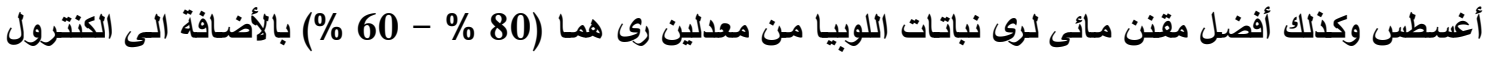
(100 \%) من الأحتياجات المائية لنباتات اللوبيا م³ /فدان والتفاعل بينهما وتأثير ذلك على النمو الخضرى لنباتات اللوبيا صنف قها 1 ومحصول البذور الجاف ومكوناته وكفاءة أستخدام المياه وبعض الصفات البات الكيماويـة فى الأوراق و البذور

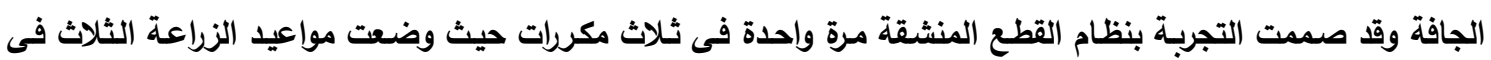
القطع الرئيسية و وزعت المقننات مياه الرى فى القطع المنثقة مرة واحدة. وقد أظهرت النتائج المتحصل عليها مايلى ماعدئان أفضل ميعاد لزراعة اللوبيا تحت ظروف هذه التجربة هو منتصف شـهر يوليو مقارنة بالمواعيد الأخرى حيث تم

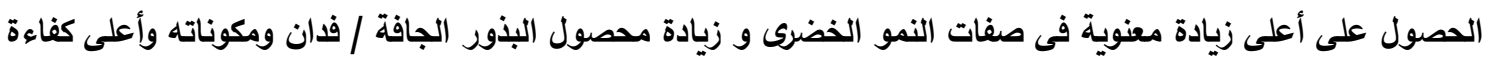

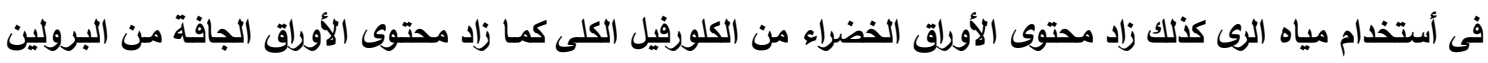

وأيضاً زادت جودة البذور الجافة نتيجة زيادة محتواها من البروتين وعناصر النتروجين والفوسفور والبوتاسيوم (\%). كما ادى رى نباتات اللوبيا بالمعدل المثالى (100 \% من الأحتياجات الفعلية للرى /فدان) مقارنة بزيادة الأجهاد المائى

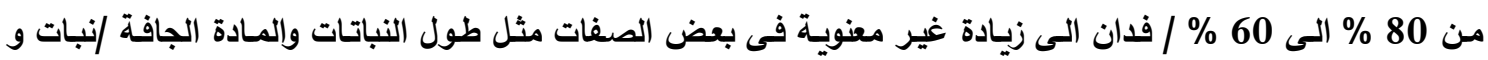

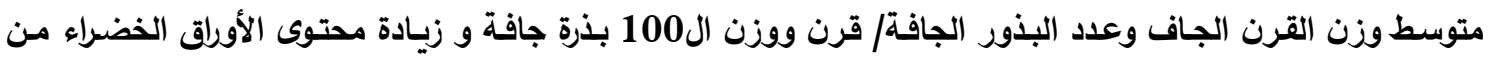
الكلورفيل الكلى.

كما ادى رى نباتات اللوبيا تحت ظروف الأجهاد المائى بمعل 80 \% /فدان من الأحتياجات الفعلية للرى /فدان) الىى

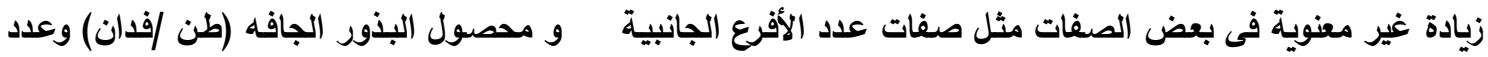

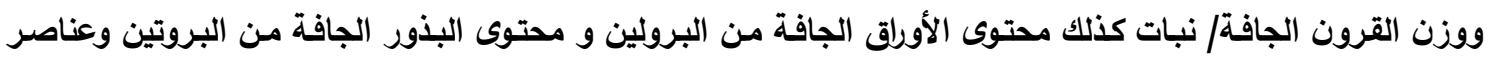

النتروجين و البوتاسيوم (\%).

كما أنخفضت كل قيم الصفات السابقة نتيجة تعرض نباتات اللوبيا لظروف الأجهاد المائى عند الرى بمعدل 60 \% من

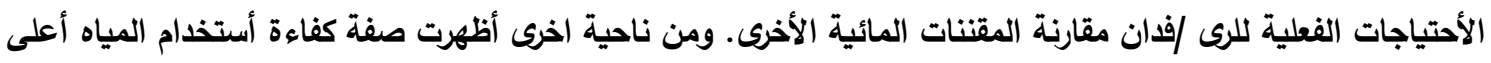

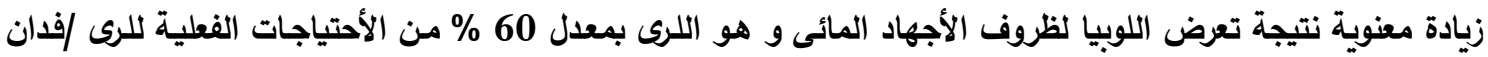

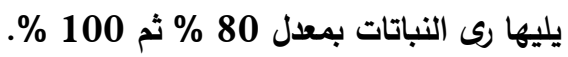

أما بالنسبة الى نتائج التفاعل بين عاملى الدراسة (مواعيد الزراعة والمقننات المائية) تحت ظروف هذا البحث فقد وجد أن أفضل تفاعل تم الحصول عليه كنتيجة لزراعة اللوبيا فى منتصف شهر يوليو ميع الرى بمعدل 80 \% من الأحتياجات 
الفعلية لرى نباتات اللوبيا /فدان حيث أدت هذ المعاملة الى زيادة معنوية و بخاصة زيادة محصول البذور الجافة وارتفاع

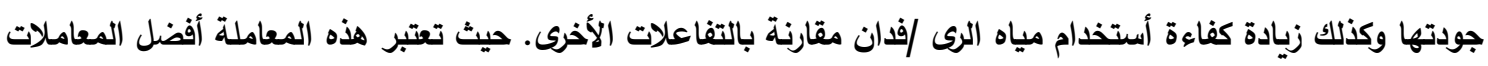
لأنتاج أعلى محصول بجودة مرتفعة مع توفير جزء من مياه الرىى.

ويمكن التوصية بزراعة بذور اللوبيا لأنتاج المحصول البذرى الجاف فى منتصف شهر يوليو والرى بمعدل 80 \% من

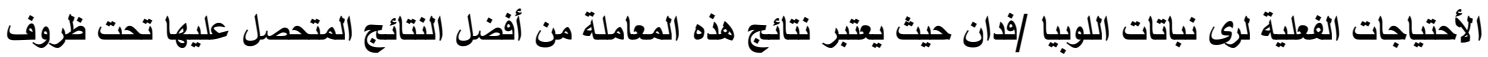

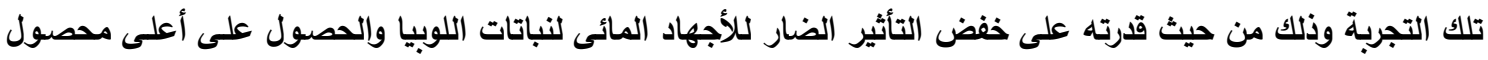

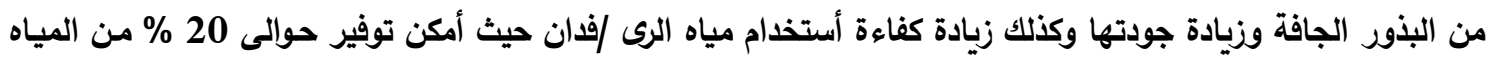

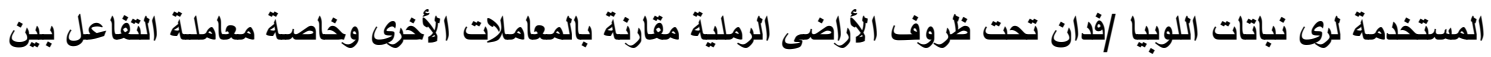
زراعة بذور اللوبيا فى الثامن والعشرون من شهر أغسطس والرى بمعدل 60 \% من الأحتياجات الفعلية لرى نباتات اللوبيا

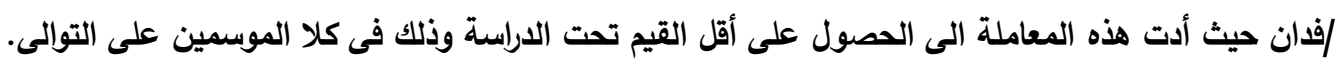
الكلمات الداله: اللوبيا ، مواعيد زراعه، المقنتات مائية، كفاءة أستخدام مياه الرى، الأراضى المستصلحة المعل حليثاً . 